\title{
DAMPAK SUBSIDI LANGSUNG TUNAI (SLT)- BBM PADA KESEJAHTERAAN KELUARGA MISKIN DI BOGOR, JAWA BARAT
}

The Effect of Direct Cash Subsidy Program to the Welfare of Poor Family in Bogor, West Java

$$
\text { Herien Puspitawati }{ }^{1} \text {, Tin } \text { Herawati }^{2} \text {, dan Ma'mun Sarma }{ }^{3}
$$

\begin{abstract}
The aim of this study was to analyze the conditions of the family who received the SLT-BBM Program regarding on the income and expenditure and intrahousehold analysis. The study was conducted at Bogor City (Sub-District of West Bogor and South Bogor) and Bogor District (Sub-District of Ciomas), West Java Province. The study implemented a survey design through the process of purposive sampling procedures. One of the criteria of the study location was the location that had the highest quantity of poor families. The samples of the family were chosen purposively from the chosen location. The total of sample was 168 families (112 families who have men as the head of the household, and 56 families who have women as the head of the household). The study used descriptive analysis that contains of observations, secondary data, news, primary data (from questionnaire), in-depth interview and focus group discussion. The results found out that around half of the samples were actually not eligible to receive the program. Around $60 \%$ of the family had monthly income per capita of Rp 100,000.00 which was below the poverty line. The study also found out that in general, every household expended around $60 \%$ of the money for food (staple food) fulfillment. Then, the money received from the program was expended by family less then a week.
\end{abstract}

Key Words: subsidy, poor family, family well-being

\section{PENDAHULUAN}

Kemiskinan masih menjadi masalah pokok bagi bangsa Indonesia yang semakin hari semakin mengkhawatirkan, terutama sejak terjadinya krisis ekonomi pada tahun 1997. Berdasarkan data Biro Pusat Statistik (BPS) secara nominal diketahui terjadi penurunan angka penduduk miskin, dari 38.4 juta jiwa pada tahun 2002, menjadi 37.3 juta jiwa $(17.4 \%)$ pada tahun 2003 , dan menjadi 36 juta jiwa keluarga miskin pada tahun 2004 yang tersebar di 31 propinsi, terdiri dari 10 juta kepala keluarga miskin dengan penghasilan rata-rata hingga $\mathrm{Rp} 150,000.00$ per bulan, dan 4 juta kepala keluarga fakir dengan penghasilan rata-rata hingga Rp 130,000.00 per bulan (Djalil 2005).

Penanggulangan masalah kemiskinan yang belum terselesaikan pada tahun 2004, menjadi semakin parah dengan naiknya harga Bahan Bakar Minyak (BBM) pada tanggal 1 Oktober 2005, yaitu meningkatnya penduduk miskin menjadi 15.7 juta kepala keluarga atau sebesar 52 juta orang (Suhartiningsih 2005). Strategi kebijakan yang dilakukan oleh pemerintah dalam menanggulangi masalah kemiskinan akibat kenaikan harga BBM tersebut adalah pelaksanaan program pemberian Subsidi Langsung Tunai (SLT)-BBM. Program diberikan kepada keluarga miskin tanpa syarat sebesar Rp 100,000.00 per bulan per keluarga selama bulan Oktober-Desember 2005 dengan total anggaran Rp 5 triliun. Kriteria penerima kartu KKB adalah keluarga miskin yang tidak mampu memenuhi kebutuhan dasar dengan

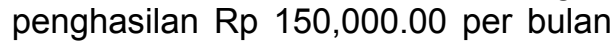
(Republika 5 Oktober 2005).

Penelitian ini difokuskan pada kajian terhadap manfaat SLT-BBM dan survival strategy keluarga miskin dalam menghadapi kesulitan hidup. Penelitian ini juga melihat pendapat sisi akademis dalam mengkaji baik buruknya kebijakan SLT-BBM bagi kelangsungan hidup rakyat miskin. 
Masalah kemiskinan semakin memprihatinkan di Indonesia. Sebelum krisis ekonomi (1996) angka kemiskinan mencapai $11.3 \%$ atau 22.5 juta jiwa dari jumlah penduduk Indonesia, sedangkan tepat sesudah krisis (1999) angka tersebut menjadi dua kali lipat, yaitu $24.2 \%$. Pada tahun 2003 angka kemiskinan turun menjadi $17.4 \%$ (37.3 juta jiwa), tetapi masih lebih tinggi dibandingkan pada saat sebelum krisis ekonomi (BPS 1998).

Program pemberian Subsidi Langsung Tunai (SLT)-BBM merupakan program pemerintah dalam membantu rakyat miskin akibat kenaikan harga bahan bakar minyak. Menurut Meneg PPN/Kepala Bappenas, Program SLT-BBM akan mengurangi jumlah penduduk miskin. Sebelum kenaikan harga BBM, jumlah penduduk miskin mencapai $16.65 \%$. Namun setelah kenaikan harga BBM, kalau tanpa SLT-BBM jumlah kemiskinan dapat mencapai $22.33 \%$ dengan tiga skenario: (1) seandainya SLT-BBM tersalurkan sempurna, yakni $28.4 \%$ masyarakat berpendidikan terendah, maka penduduk miskin turun menjadi $12.69 \%$, (2) bila SLT-BBM meleset sampai dengan $40 \%$, jumlah penduduk miskin turun menjadi $14.75 \%$, dan (3) bila SLT-BBM meleset sampai dengan $60 \%$, jumlah penduduk miskin turun menjadi $17.45 \%$.

Selanjutnya Meneg PPN/Kepala Bappenas mengklaim bahwa SLTBBM adalah program terbesar di dunia karena mencakup 15.5 juta rumah tangga. Sampai dengan bulan Oktober 2005 telah tersalurkan kepada 10.2 juta rumah tangga dengan total dana yang didistribusikan secara nasional sebesar Rp 2.9 triliun dari Rp 4.5 triliun (Republika 1 November 2005). Banyak berita di media massa yang menginformasikan tentang ketidaktepatan sasaran penerima SLTBBM di daerah, diantaranya adanya penerima SLT-BBM yang bekerja sebagai PNS, dan adanya sebagian keluarga yang cukup mampu mendapatkan dana bantuan SLTBBM.

Sebagai contoh, untuk Kota Bogor distribusi Program SLT-BBM dilakukan melalui enam kantor bayar dengan jumlah jangkauan pelayanan mencakup 39,162 kepala keluarga dengan total penyaluran sejumlah $\mathrm{Rp}$ $11,748,600,000.00$. Diantara enam kantor pembayaran di Kota Bogor, wilayah Kecamatan Bogor Barat adalah yang terbanyak cakupan pelayanannya, yaitu meliputi 10,458 kepala keluarga dengan besaran uang Rp 3.137 milyar, kemudian berturutturut diikuti oleh kantor pembayaran wilayah Kecamatan Bogor Timur dan Bogor Selatan yang masing-masing melayani 8,531 dan 8,313 kepala keluarga dengan besaran uang Rp 2.559 milyar dan Rp 2.494 milyar. Adapun jumlah Kartu Kompensasi BBM (KKB) yang ditarik meliputi 765 rumah tangga. Selanjutnya, jumlah rumah tangga miskin susulan di Kota Bogor adalah sebesar 31,506 kepala keluarga.

Sedangkan untuk Kabupaten Bogor distribusi Program SLT-BBM dilakukan melalui 15 kantor bayar dengan jangkauan pelayanan mencakup 149,028 kepala keluarga dengan total penyaluran sejumlah Rp 44,708,400,000.00. Diantara 15 kantor pembayaran di Kabupaten Bogor, wilayah Kecamatan Cibungbulang adalah yang terbanyak cakupan pelayanannya, yaitu meliputi 21,105 kepala keluarga dengan besaran uang $\operatorname{Rp} 6,332$ milyar, kemudian berturut-turut diikuti oleh kantor pembayaran wilayah Kecamatan Cigombong dan Leuwiliang yang masing-masing melayani 19,516 dan 19,376 kepala keluarga dengan besaran uang Rp 5.855 milyar dan Rp 5.813 milyar.

Mengingat semakin besarnya tantangan di masa depan, maka studi ini secara umum bertujuan untuk mengetahui manfaat Program Pemberian Subsidi Langsung Tunai (SLT) BBM pada rumahtangga miskin 
di pedesaan maupun di perkotaan. Secara khusus, studi ini bertujuan untuk: (1) Melakukan verifikasi secara sampling sederhana mengenai kriteria rumah tangga miskin penerima Program SLT-BBM sesuai dengan kriteria BPS; (2) Menganalisis pendapatan dan pengeluaran rumah tangga penerima Program SLT-BBM; (3) Menguraikan dan menganalisis permasalahan kehidupan rumah tangga (masalah sosial, ekonomi, pembagian peran dan tanggung jawab anggota keluarga, hubungan antar anggota keluarga/dukungan sosial antar anggota keluarga, hubungan dengan keluarga besar, hubungan dengan tetangga); (4) Menguraikan dan menganalisis secara global manfaat Program Pemberian Subsidi Langsung Tunai (SLT) BBM bagi rumah tangga miskin

\section{METODE PENELITIAN}

Tempat dan Waktu

Penelitian dilakukan di Kota Bogor (Kecamatan Bogor Barat dan Bogor Selatan) dan Kabupaten Bogor (Kecamatan Ciomas), Propinsi Jawa Barat. Pengambilan data dilakukan selama 2 bulan yaitu pada bulan Januari sampai dengan Februari 2004. Penelitian ini menggunakan desain survey, yaitu diambil secara sengaja (pusposive) dengan salah satunya mempertimbangkan faktor lokasi berdasarkan data keluarga miskin terbanyak yang mendapatkan SLTBBM di Kota Bogor. Lokasi penelitian yaitu dipilih dua tempat di kotamadya dan satu tempat di kabupaten dengan pertimbangan kecamatan yang cenderung mempunyai angka kemiskinan tertinggi berdasarkan data terakhir dari Badan Pusat Statistik (BPS). Contoh yang diambil untuk penelitian yaitu rumah tangga miskin yang mendapatkan dana SLT-BBM.

Metode Pengambilan Contoh

Rumahtangga yang dijadikan
contoh penelitian dipilih secara purposive dari lokasi yang terbanyak menerima SLT-BBM. Berdasarkan data dari Kantor Pos sebagai distributor SLT-BBM, maka untuk wilayah Kota Bogor dipilih lokasi Kecamatan Bogor Barat yang terbanyak cakupan pelayanannya, yaitu meliputi 10,458 kepala keluarga dengan besaran uang Rp 3.137 milyar dan kecamatan Bogor Selatan. Sedangkan untuk Kabupaten Bogor dipilih wilayah Kecamatan Ciomas yang cakupan pelayanannya cukup banyak, yaitu meliputi 21,105 kepala keluarga dengan besaran uang Rp 6.332 milyar. Contoh atau responden yang digunakan pada penelitian ini merupakan rumah tangga miskin yang dipilih secara purposive dengan pertimbangan data dari BPS dan Kantor Pos Pusat Bogor tentang keluarga penerima SLT-BBM. Jumlah contoh yang diambil yaitu sebanyak 108 untuk lokasi di Kota Bogor dan 60 untuk di lokasi Kabupaten Bogor.

Penarikan contoh di Kota Bogor yang berlokasi di Kecamatan Bogor Selatan yaitu dipilih secara purposive berdasarkan jumlah keluarga penerima SLT-BBM terbanyak yaitu Kelurahan Empang, sedangkan untuk lokasi Kecamatan Bogor Barat yaitu Kelurahan Situ Gede. Penarikan contoh serupa juga dilakukan di Kabupaten Bogor yaitu di Kecamatan Ciomas, tepatnya di Kelurahan Laladon sebagai lokasi penelitian.

Jenis dan Cara Pengumpulan Data

Data yang dikumpulkan terdiri atas data primer dan data sekunder. Data primer dikumpulkan dengan berbagai metode seperti wawancara menggunakan kuesioner, pengamatan langsung pada saat melakukan wawancara di rumah contoh.

Sedangkan untuk data sekunder yang dikumpulkan meliputi data potensi desa, data monografi desa, data penduduk miskin dan penerima SLT-BBM pada bulan OktoberDesember 2005, data BKKBN dan BPS serta dokumentasi lain yang 
berkenaan dengan penelitian. Data primer yang diambil meliputi:

1. Karakteristik sosial, ekonomi, dan demografi rumah tangga penerima SLT-BBM.

2. Peran dan tanggung jawab anggota rumah tangga.

3. Pola pendapatan dan pengeluaran rumah tangga.

4. Alur penggunaan dana Rp 300,000.00 bagi rumah tangga.

5. Manfaat SLT-BBM bagi penduduk miskin.

Metode pengumpulan data/ informasi yang diterapkan pada penelitian ini adalah bervariasi sebagai berikut:

1. In desk study untuk mendapatkan berbagai informasi dari media cetak maupun elektronik, dari Kantor Pos maupun Kantor Statistik Kota dan Kabupaten Bogor.

2. Pengamatan yang cermat di lapangan pada rumah tangga penerima SLT-BBM pada saat pengambilan data primer.

3. Pengamatan beberapa hari di lapangan pada saat pemberian subsidi selanjutnya pada bulan Februari 2006.

4. Metode survey pada sejumlah rumah tangga penerima dengan menggunakan kuesioner terstruktur.

5. In depth interview dengan aparat pemerintahan tentang kebijakan SLT-BBM.

\section{Pengolahan dan Analisis Data}

Data primer yang telah dikumpulkan melalui wawancara diolah melalui proses editing, koding, scoring, entry data ke komputer, serta cleaning dan analisis data. Koding atau yang biasa disebut code book dilakukan di dalam kuesioner yang ditulis pada masing-masing pertanyaan, sehingga diperoleh jenisjenis kode. Sedangkan untuk pemberian skor ditujukan pada setiap variabel (kecuali untuk pertanyaan terbuka), kemudian skor tersebut dijumlahkan menjadi satu variabel komposit.

Interval kelas (I) dapat dihitung dengan cara sebagai berikut :

$$
\begin{aligned}
& I=\frac{\text { Skor Maksimum (NT) }- \text { Skor Minimum (NR) }}{\sum \text { Kategori }} \\
& \text { Ket : } \begin{array}{ll}
\text { Kurang } & =\text { NR- }(N R+I) \\
\text { Sedang } & =(N R+I)-[(N R+I)+I] \\
\text { Baik } & =[(N R+I)+I]-N T
\end{array}
\end{aligned}
$$

Data-data tersebut kemudian diolah secara komputerisasi dengan menggunakan Program Microsoft Excel dan Program SPSS versi 11.0 for Windows.

Data yang terkumpul kemudian diberi skor sesuai dengan tingkatan masalahnya. Analisis yang akan dipergunakan dalam studi ini adalah analisis deskriptif yang meliputi penjelasan pemaknaan dari pengamatan, data sekunder, berita koran, in-depth interview dan diskusi fokus grup.

\section{HASIL DAN PEMBAHASAN}

Karakteristik Sosial dan Demografi Responden

Pada umumnya tingkat pendidikan Kepala Keluarga (KK) pada penelitian ini adalah tidak tamat SD $(33.0 \%)$ sampai dengan tamat SD (38.4\%). Hal ini menunjukkan rendahnya tingkat pendidikan KK responden. Tingkat pendidikan tertinggi $\mathrm{KK}$ hanya tamat SMA (8.9\%). Tingkat pendidikan yang rendah juga ditemukan pada istri. Hal ini ditunjukkan oleh sebagian besar pendidikan yang dialami istri adalah tidak tamat SD (33.7\%) dan tamat SD (33.1\%). Tingkat pendidikan tertinggi istri hanya tamat SMA yaitu sebanyak $3.7 \%$.

Sebagian besar KK bekerja sebagai buruh $(57.2 \%)$ bahkan lebih dari seperlima KK (23.2\%) pada saat penelitian berlangsung tidak memiliki pekerjaan. Hasil penelitian menunjukkan bahwa lebih dari setengah jumlah istri adalah sebagai ibu rumah tangga (64.4\%). Lebih dari 
setengah jumlah responden memiliki jumlah anggota keluarga antara 5-8 orang (56.5\%). Rata-rata jumlah anggota keluarga adalah 5.36 orang .

Rata-rata pendapatan total keluarga secara keseluruhan adalah Rp 421,796.00. Berdasarkan pendapatan per kapita per bulan, maka proporsi tertinggi (38.7\%) jumlah responden memiliki pendapatan per kapita kurang dari Rp 50,000.00. Dengan demikian dapat dikatakan bahwa ada sekitar $60 \%$ responden berada di bawah garis kemiskinan (Garis Kemiskinan Kota Bogor adalah Rp 133,803.00 per kapita per bulan dan Kabupaten Bogor adalah Rp 105,888.00 per kapita per bulan pada tahun 2003). Secara keseluruhan rata-rata pendapatan per kapita per bulan responden adalah Rp 90,978.27.

Hasil analisis menunjukkan bahwa pengeluaran yang paling banyak digunakan adalah untuk pangan pokok, yaitu rata-rata $\mathrm{Rp} 163,689.80$ per bulan. Selain itu juga pengeluaran untuk jajan menunjukkan jumlah yang cukup tinggi. Dari 94 responden yang mengeluarkan uang jajan maka ratarata uang untuk jajan per bulan adalah Rp 116,193.60. Hasil penelitian menunjukkan bahwa pengeluaran untuk rokok hampir sama dengan pengeluaran untuk lauk pauk dan minyak tanah, yaitu lebih dari Rp 80,000.00 per bulan. Sebanyak $17.3 \%$ responden mengeluarkan uang per bulan untuk membeli pakaian sekitar Rp 45,993.10. Jenis pengeluaran lain yang dikeluarkan responden dengan jumlah dibawah Rp 50,000.00 per bulan adalah untuk sayur, minyak goreng, kesehatan, listrik, dan bayar hutang. Sedangkan pengeluaran responden yang berkisar antara Rp 50,000.00 - Rp 70,000.00 per bulan adalah pendidikan, transportasi, arisan, kredit, sewa rumah, dan acara undangan. Jumlah responden yang mengeluarkan uang untuk arisan, kredit, bayar hutang, sewa rumah, dan acara undangan hanya sebagian kecil saja.

Verifikasi Kriteria Rumah Tangga Miskin Penerima SLT-BBM

Hasil penelitian menunjukkan bahwa dari 168 responden yang menerima SLT-BBM terdapat lebih dari tiga perempat responden memiliki sumber air minum berasal dari sumur/ mata air tidak terlindung/sungai/air hujan $(87.5 \%)$; hanya membeli satu stel pakaian baru dalam setahun (77.4\%); sanggup makan sebanyak satu/dua kali dalam sehari (85.7\%); sumber penghasilan kepala rumah tangga adalah petani dengan luas lahan 0.5 ha, buruh tani, nelayan, buruh bangunan, buruh perkebunan, atau pekerjaan lainnya dengan pendapatan dibawah Rp 600.000 per bulan $(77.4 \%)$; pendidikan tertinggi kepala rumah tangga tidak sekolah/tidak tamat SD/hanya SD (86.3\%); bahkan semua menggunakan bahan bakar untuk memasak sehari-hari dari kayu bakar/arang/minyak tanah (100\%).

Selain itu terdapat sekitar setengah sampai tiga perempat responden yang memiliki luas lantai bangunan tempat tinggal kurang dari delapan meter persegi $\left(<8 \mathrm{~m}^{2}\right)$ per orang (50.6\%); hanya mengkonsumsi daging/susu/ayam satu kali dalam seminggu (61.3\%); dan tidak memiliki tabungan/barang yang mudah dijual dengan nilai minimal $\operatorname{Rp~} 500,000.00$ seperti: sepeda motor (kredit/nonkredit), emas, ternak, atau barang modal lainnya (73.8\%). Sedangkan jumlah responden yang memiliki jenis lantai rumah dari tanah/bambu/kayu murahan, dinding dari bambu/ rumbia/kayu berkualitas rendah/ tembok tanpa di plester, tidak memiliki fasilitas buang air besar/bersamasama dengan rumah tangga lain dan tidak sanggup membayar biaya pengobatan di puskesmas/poliklinik dibawah $50 \%$. Pada penelitian ini juga ditemukan sebanyak $14.3 \%$ responden 
yang tidak menggunakan listrik sebagai sumber penerangan.

Tabel 1 menjelaskan verifikasi kriteria kemiskinan. Hasil menunjukkan bahwa sebanyak 54.2\% keluarga contoh terbukti tidak memenuhi persyaratan atau dinyatakan salah sasaran. Sesuai dengan peraturan yang dikeluarkan oleh BPS (2005), dinyatakan bahwa kriteria rumah tangga yang layak mendapatkan SLT adala rumah tangga yang memenuhi minimal 9 atau lebih ciri rumah tangga miskin.

Tabel 1. Sebaran Responden berdasarkan Verifikasi Kriteria Kemiskinan

\begin{tabular}{|l|r|r|}
\hline \multirow{2}{*}{ Kategori Memenuhi } & \multicolumn{2}{|c|}{ Total } \\
\cline { 2 - 3 } & \multicolumn{1}{|c|}{$\mathbf{n}$} & \multicolumn{1}{c|}{$\%$} \\
\hline $3-5$ & 20 & 11.9 \\
\hline $6-8$ & 71 & 42.3 \\
\hline $9-14^{*}$ & 77 & 45.8 \\
\hline Total & 168 & 100.0 \\
\hline
\end{tabular}

Keterangan : * yang layak menerima SLT

Permasalahan Keluarga Sebelum dan Sesudah Kenaikan Harga BBM

Permasalahan responden sesudah kenaikan harga BBM nampaknya lebih banyak dibandingkan sebelum kenaikan harga BBM (Tabel 2). Masalah yang paling banyak dialami keluarga sebelum kenaikan BBM adalah kesulitan keuangan keluarga $(63.7 \%)$ dan minimnya aset keluarga (52.4\%). Sebagain besar responden (95.8\%) tidak mengalami masalah hubungan/ konflik dengan tetangga, hal ini terlihat sebelum dan sesudah kenaikan BBM. Sedangkan masalah hubungan/konflik dengan keluarga meningkat setelah terjadi kenaikan harga BBM, yaitu menjadi $19.6 \%$ dan sebelumnya hanya $12.5 \%$.

Kondisi yang sama juga terlihat bahwa permasalahan yang paling banyak dihadapi oleh keluarga setelah kenaikan harga BBM adalah masalah keuangan keluarga. Jumlah keluarga yang mengalami kondisi tersebut meningkat tajam, yaitu menjadi $89.3 \%$ pada saat sesudah kenaikan harga BBM. Masalah lain yang banyak dialami keluarga sesudah kenaikan harga BBM adalah masalah ketersediaan makanan (66.7\%) dan pekerjaan yang tidak menentu $(56.5 \%)$. Pada saat sebelum kenaikan BBM, masalah-masalah tersebut hanya dialami kurang dari $50 \%$ responden. Sedangkan minimnya aset keluarga tetap menjadi masalah pada saat sesudah kenaikan harga BBM (54.8\%). Jumlah tersebut tidak banyak berubah dibandingkan sebelum kenaikan harga BBM. Masalahmasalah lain yang dihadapi keluarga adalah pendidikan anak, kesehatan keluarga, tempat tinggal yag minim, suami tidak memiliki pekerjaan, suami merokok setiap hari, pembagian tugas suami isteri dan beban pekerjaan isteri menjadi berat.

Secara umum terdapat banyak masalah yang dihadapi keluarga pada saat sebelum maupun sesudah kenaikan BBM. Perbedaan yang terjadi adalah jumlah keluarga yang mengalami masalah menjadi meningkat setelah terjadi kenaikan BBM. Hal ini menunjukkan bahwa kondisi sosial ekonomi keluarga yang semakin tidak stabil dan semakin menurun.

Jika dikelompokkan menjadi tiga kategori, yaitu ringan, sedang dan berat maka sebagian besar keluarga (64.9\%) memiliki permasalahan yang ringan pada saat sebelum kenaikan harga BBM (Tabel 3). Sedangkan pada saat sesudah kenaikan harga BBM, sebagian besar keluarga (56\%) memiliki permasalahan dengan kategori sedang, bahkan yang berat meningkat menjadi $5.4 \%$. 
Tabel 2. Permasalahan Keluarga Sebelum dan Sesudah Kenaikan BBM

\begin{tabular}{|c|c|c|c|c|c|c|c|c|c|}
\hline \multirow{3}{*}{ No } & \multirow{3}{*}{ Pernyataan } & \multicolumn{4}{|c|}{ Sebelum } & \multicolumn{4}{|c|}{ Sesudah } \\
\hline & & \multicolumn{2}{|c|}{ Tidak } & \multicolumn{2}{|c|}{ Ya } & \multicolumn{2}{|c|}{ Tidak } & \multicolumn{2}{|c|}{ Ya } \\
\hline & & $\mathbf{n}$ & $\%$ & $\mathbf{n}$ & $\%$ & $\mathbf{n}$ & $\%$ & $\mathbf{n}$ & $\%$ \\
\hline 1 & Masalah Ketersediaan Makanan & 114 & 67.9 & 54 & 32.1 & 56 & 33.3 & 112 & 66.7 \\
\hline 2 & Kesulitan keuangan keluarga & 61 & 36.3 & 107 & 63.7 & 18 & 10.7 & 150 & 89.3 \\
\hline 3 & $\begin{array}{l}\text { Masalah pekerjaan yang tidak } \\
\text { menentu }\end{array}$ & 92 & 54.8 & 76 & 45.2 & 73 & 43.5 & 95 & 56.5 \\
\hline 4 & $\begin{array}{l}\text { Masalah jaminan pendidikan } \\
\text { anak }\end{array}$ & 115 & 68.5 & 53 & 31.5 & 100 & 59.5 & 68 & 40.5 \\
\hline 5 & Masalah kesehatan keluarga & 122 & 72.6 & 46 & 27.4 & 97 & 57.7 & 71 & 42.3 \\
\hline 6 & $\begin{array}{l}\text { Masalah hubungan/ konflik } \\
\text { dalam keluarga }\end{array}$ & 147 & 87.5 & 21 & 12.5 & 135 & 80.4 & 33 & 19.6 \\
\hline 7 & $\begin{array}{l}\text { Masalah hubungan/ konflik } \\
\text { dengan tetangga }\end{array}$ & 161 & 95.8 & 7 & 4.2 & 161 & 95.8 & 7 & 4.2 \\
\hline 8 & $\begin{array}{l}\text { Masalah minimnya tempat } \\
\text { tinggal }\end{array}$ & 118 & 70.2 & 50 & 29.8 & 112 & 66.7 & 56 & 33.3 \\
\hline 9 & Masalah minimnya aset keluarga & 80 & 47.6 & 88 & 52.4 & 76 & 45.2 & 92 & 54.8 \\
\hline 10 & $\begin{array}{l}\text { Masalah suami tdk punya } \\
\text { pekerjaan tetap }\end{array}$ & 117 & 69.6 & 51 & 30.4 & 102 & 60.7 & 66 & 39.3 \\
\hline 11 & $\begin{array}{l}\text { Masalah suami merokok tiap } \\
\text { hari }\end{array}$ & 122 & 72.6 & 46 & 27.4 & 114 & 67.9 & 54 & 32.1 \\
\hline 12 & $\begin{array}{l}\text { Masalah pembagian tugas } \\
\text { suami istri }\end{array}$ & 142 & 84.5 & 26 & 15.5 & 140 & 83.3 & 28 & 16.7 \\
\hline 13 & $\begin{array}{l}\text { Masalah beban pekerjaan istri } \\
\text { yg berat }\end{array}$ & 123 & 73.2 & 45 & 26.8 & 107 & 63.7 & 61 & 36.3 \\
\hline
\end{tabular}

Tabel 3. Sebaran Responden Berdasarkan Kategori Permasalahan Keluarga Sebelum dan Sesudah Kenaikan Harga BBM

\begin{tabular}{|l|r|r|r|r|}
\hline \multirow{2}{*}{ Kategori } & \multicolumn{2}{|c|}{ Sebelum } & \multicolumn{2}{c|}{ Sesudah } \\
\cline { 2 - 5 } & $\mathbf{n}$ & \multicolumn{1}{c|}{$\%$} & \multicolumn{1}{c|}{$\mathbf{n}$} & \multicolumn{1}{c|}{$\%$} \\
\hline $\begin{array}{l}\text { Ringan } \\
(13-17)\end{array}$ & 109 & 64.9 & 65 & 38.7 \\
\hline $\begin{array}{l}\text { Sedang } \\
(18-22)\end{array}$ & 53 & 31.5 & 94 & 56.0 \\
\hline $\begin{array}{l}\text { Tinggi } \\
(23-26)\end{array}$ & 6 & 3.6 & 9 & 5.3 \\
\hline Total & 168 & 100.0 & 168 & 100.0 \\
\hline
\end{tabular}

Alur Pembelanjaan Uang SLT-BBM

Setengah dari jumlah uang SLTBBM digunakan responden untuk belanja pangan. Rata-rata uang SLTBBM yang dibelanjakan untuk pangan adalah Rp 150,375.00 (Tabel 4). Selain untuk belanja pangan, responden juga menggunakan uang SLT untuk keperluan perumahan, pendidikan, kesehatan, pakaian, bayar hutang, membeli rokok untuk suami, modal, memberi ke saudara dan anak, zakat, menabung, transportasi, listrik, dan lain-lain. Diantara keperluankeperluan tersebut, maka penggunaan uang SLT-BBM untuk keperluan bayar hutang, membeli pakaian, keperluan kesehatan dan pendidikan relatif lebih tinggi dibandingkan keperluan lainnya. Uang SLT-BBM yang digunakan untuk keperluan tersebut sekitar $6.6-9.8 \%$.

Tabel 4. Alur Pembelanjaan Uang SLT

\begin{tabular}{|l|c|c|}
$\begin{array}{l}\text { Uraian } \\
\text { Pengeluaran }\end{array}$ & Rata-rata Pembelanjaal & \%* \\
\hline Pangan & $150,375.00 \pm 97,007.99$ & 50.1 \\
\hline Perumahan & $4,077.38 \pm 24,351.71$ & 1.4 \\
\hline Pendidikan & $19,863.10 \pm 58,393.35$ & 6.6 \\
\hline Kesehatan & $22,094.67 \pm 63,584.03$ & 7.4 \\
\hline Pakaian & $22,877.98 \pm 63,584.03$ & 7.6 \\
\hline Bayar hutang & $29,313.61 \pm 60,726.47$ & 9.8 \\
\hline Rokok & $1,547.62 \pm 9539.59$ & 0.5 \\
\hline Modal & $12,654.76 \pm 47,584.28$ & 4.2 \\
\hline $\begin{array}{l}\text { Memberi ke } \\
\text { anak }\end{array}$ & $2,678.57 \pm 10,678.94$ & 0.9 \\
\hline $\begin{array}{l}\text { Memberi ke } \\
\text { saudara }\end{array}$ & $2,142.86 \pm 14,482.81$ & 0.7 \\
\hline Zakat & $6,630.95 \pm 20,020.14$ & 2.2 \\
\hline Menabung & $6,345.24 \pm 25,693.43$ & 2.1 \\
\hline Transport & $7,708.33 \pm 29,843.17$ & 2.6 \\
\hline Listrik & $4,422.62 \pm 13,879.07$ & 1.5 \\
\hline Lain-lain & $7,267.38 \pm 34.535 .25$ & 2.4 \\
\hline Keterangan : ${ }^{*}$ ers & & \\
\hline
\end{tabular}

Keterangan : " persentase dari Rp 300,000.00

Rata-rata uang SLT-BBM yang digunakan untuk membayar hutang adalah Rp 29,313.61 untuk membeli 
pakaian Rp 22,877.98, keperluan kesehatan Rp 22,094.67 dan untuk pendidikan adalah sebesar Rp 19,863.10. Sedangkan untuk keperluan lainnya, uang SLT-BBM yang digunakan sekitar $2.4 \%$. Meskipun kecil jumlahnya, responden juga menggunakan uang SLT-BBM untuk membeli rokok suaminya. Rata-rata uang SLT-BBM yang dibelanjakan untuk rokok adalah Rp 1,547.62 atau sekitar $0.5 \%$.

Uang SLT-BBM yang diterima rata-rata habis dalam tempo 11 hari. Proporsi tertinggi responden (38.1\%) dalam menghabiskan uang SLT-BBM adalah antara 2-7 hari. Bahkan yang habis dalam satu hari mencapai $28.0 \%$. Selain itu juga ada sekitar $3.6 \%$ responden yang dapat menghabiskan uang SLT-BBM dalan jangka waktu lebih dari satu bulan.

Hampir setengah (49.4\%) dari jumlah responden menyatakan bahwa penerima uang SLT-BBM adalah suami dan sepertiga lebih (39.3\%) sebagai penerimanya adalah istri. Keadaan yang cukup mengkhawatirkan adalah bahwa yang menerima SLT-BBM adalah calo, meskipun dinyatakan oleh $0.6 \%$ responden.

Jika uang tersebut diambil oleh suami, maka ada $15.7 \%$ suami (13 orang suami) yang tidak menyerahkan semua uang SLT-BBM kepada isterinya. Jumlah uang yang diserahkan kepada isterinya bervariasi yaitu Rp 30,000.00 (7.7\%), Rp $100,000.00$ (15.4\%), Rp 150,000.00 (30.8\%), Rp 170,000.00 (7.7\%), Rp $200,000.00 \quad(30.8 \%)$ dan Rp $280,000.00(7.7 \%)$.

Pembagian Tugas Suami dan Isteri dalam Keluarga

Hasil penelitian menunjukkan bahwa mengatur penyediaan makanan, mengatur kegiatan rumah tangga, bertanggung jawab pekerjaan domestik dan manajemen keuangan keluarga termasuk memutuskan untuk membelanjakan uang SLT-BBM, mengelola uang SLT-BBM, merencanakan keuangan keluarga, memegang/mengatur uang SLT-BBM adalah menjadi tugas isteri. Hal tersebut dinyatakan oleh lebih dari $70 \%$ responden (Tabel 5). Beberapa hal yang pada umumnya menjadi tugas bersama (suami dan istri) adalah dalam hal mencari jalan pemecahan masalah keuangan, bertanggung jawab dalam aktivitas sosial, serta pengasuhan dan pendidikan anak. Jika dilihat pada Tabel 5 maka pembagian tugas suami dalam keluarga relatif lebih rendah. Ada satu hal yang dianggap cukup tinggi keterlibatan suami dalam keluarga dibanding hal yang lain adalah bertanggung jawab pekerjaan publik/ ekonomi $(25.6 \%)$.

Tabel 5. Pembagian Tugas Suami dan Istri dalam Keluarga

\begin{tabular}{|c|c|c|c|c|c|c|c|}
\hline \multirow{2}{*}{ No } & \multirow{2}{*}{ Pernyataan } & \multicolumn{2}{|c|}{ Istri } & \multicolumn{2}{|c|}{ Isteri \& suami } & \multicolumn{2}{|c|}{ Suami } \\
\hline & & $\mathbf{n}$ & $\%$ & $\mathbf{N}$ & $\%$ & $\mathbf{n}$ & $\%$ \\
\hline 1. & Memutuskan utk membelanjakan uang SLT & 127 & 75.6 & 29 & 17.3 & 12 & 7.1 \\
\hline 2. & Mengelola uang SLT & 123 & 73.2 & 31 & 18.5 & 14 & 8.3 \\
\hline 3. & Merencanakan keuangan keluarga & 123 & 73.2 & 33 & 19.6 & 12 & 7.1 \\
\hline 4. & Memegang/ mengatur keuangan keluarga & 139 & 82.7 & 14 & 8.3 & 15 & 8.9 \\
\hline 5. & Mengontrol pengeluaran keuangan & 126 & 75.0 & 19 & 11.3 & 23 & 13.7 \\
\hline 6. & Mengatur penyediaan makanan keluarga & 148 & 88.1 & 10 & 6.0 & 10 & 6.0 \\
\hline 7. & Mengatur kegiatan rumahtangga & 131 & 78.0 & 28 & 16.7 & 9 & 5.4 \\
\hline 8. & Mencari jalan pemecahan masalah keuangan & 77 & 45.8 & 80 & 47.6 & 11 & 6.5 \\
\hline 9. & Bertanggung jawab pekerjaan domestik & 115 & 68.5 & 45 & 26.8 & 8 & 4.8 \\
\hline 10. & Bertanggung jawab pekerjaan publik/ekonomi & 63 & 37.5 & 62 & 36.9 & 43 & 25.6 \\
\hline 11. & Bertanggung jawab aktivitas sosial & 67 & 39.9 & 93 & 55.4 & 8 & 4.8 \\
\hline 12. & Bertanggung jawab pengasuhan \& pendidikan anak & 77 & 45.8 & 88 & 52.4 & 3 & 1.8 \\
\hline
\end{tabular}


Frekuensi Konsumsi Sebelum dan Sesudah Kenaikan Harga BBM

Semua responden mengkonsumsi beras setiap hari pada saat sebelum kenaikan harga BBM. Jenis pangan lain yang banyak dikonsumsi responden setiap hari adalah sayuran hijau, ikan asin, kopi/gula dan minyak goreng. Proporsi tertinggi responden (42.9-47.6\%) menyatakan bahwa tempe, tahu dan rokok juga dikonsumsi setiap hari. Sedangkan jenis pangan yang termasuk jarang dikonsumsi oleh responden adalah daging, ikan segar, ayam, dan buah. Meskipun mereka mengkonsumsi hanya 1-3 kali/bulan bahkan untuk daging lebih dari sebulan. Sumber protein hewani yang dianggap sering dikonsumsi adalah telur. Sebanyak $39.9 \%$ responden mengkonsumsi telur dengan frekuensi 1-3 kali per minggu dan $28.6 \%$ dengan frekuensi $4-6$ kali per minggu.

Keadaan konsumsi responden menunjukkan adanya perbedaan setelah kenaikan harga BBM. Berdasarkan hasil penelitian menunjukkan bahwa responden yang mengkonsumsi beras setiap hari menurun menjadi $99.4 \%$, dan $0.6 \%$ berubah frekuensinya menjadi 4-6 kali per minggu. Jenis pangan yang banyak dikonsumsi sesudah kenaikan harga BBM sama seperti sebelum kenaikan harga BBM yaitu sayuran hijau, ikan asin, minyak goreng, rokok dan kopi/gula. Perbedaan yang terjadi setelah kenaikan harga BBM adalah responden yang mengkonsumsi pangan tersebut dengan frekuensi setiap hari menurun, sedangkan frekuensi 4-6 kali per minggu dan 1-3 kali per minggu justru menunjukkan adanya peningkatan. Telur merupakan jenis protein hewani yang masih banyak dikonsumsi setelah kenaikan harga BBM. Sedangkan ikan segar, daging, ayam dan buah jenis pangan yang jarang dikonsumsi, bahkan jumlah responden yang tidak pernah mengkonsumsi lebih dari $40 \%$. Responden yang mengkonsumsi tahu dan tempe dengan frekuensi per hari juga menurun sesudah kenaikan harga BBM dan peningkatan jumlah responden terlihat pada frekuensi 1-3 kali per minggu.

Berdasarkan data diatas maka secara umum responden mengurangi kuantitas dan kualitas jenis pangan yang dikonsumsi setelah kenaikan harga BBM. Hal ini adalah sebagai konsekuensi dari tingkat sosial ekonomi responden yang semakin menurun setelah kenaikan harga BBM.

Perubahan yang Terjadi pada Keluarga Setelah Kenaikan BBM

Hasil penelitian ini menunjukkan meskipun hubungan dalam keluarga tetap saat sesudah kenaikan harga BBM tetapi konflik/pertengkaran dalam keluarga meningkat dan hal ini dinyatakan oleh $78 \%$ responden. Kondisi yang sangat mengkhawatirkan adalah bahwa sesudah kenaikan BBM ternyata kekerasan dalam rumah tangga juga meningkat. Pernyataan tersebut diungkapkan oleh 95.\% responden. Kondisi lain yang terjadi sesudah kenaikan BBM adalah tidak ada uang yang ditabung, hal ini dialami oleh $92.3 \%$ responden. Sebanyak lebih dari setengah responden (51.8\%) menyatakan bahwa pendapatan total mereka juga menurun, tetapi pengeluaran pangan dan non pangan menjadi meningkat (Tabel 6).

Perubahan yang kurang baik juga terjadi pada kualitas pendidikan anak. Hal ini terlihat dari proporsi tertinggi responden $(48.8 \%)$ yang menyatakan bahwa kualitas pendidikan anaknya menurun. Tetapi ada juga sebanyak $41.7 \%$ responden menyatakan bahwa kualitas pendidikan anaknya tidak berubah (tetap) setelah kenaikan harga BBM. Hal lain yang banyak dirasakan menurun sesudah kenaikan BBM adalah penguasaan aset. Sedangkan hal lain yang dianggap tetap adalah kualitas kesehatan keluarga dan hubungan sosial dengan tetangga (67.9-73.2\%). 
Tabel 6. Sebaran Responden berdasarkan Penerimaan Keluarga tentang Perubahanperubahan antara Sebelum dan Sesudah Kenaikan Harga BBM (Oktober 2005)

\begin{tabular}{|l|r|r|r|r|r|r|r|r|}
\hline \multirow{2}{*}{ Pernyataan } & \multicolumn{2}{c|}{ Tidak ada } & \multicolumn{2}{c|}{ Turun } & \multicolumn{2}{c|}{ Tetap } & \multicolumn{2}{c|}{ Naik } \\
\cline { 2 - 10 } & \multicolumn{1}{|c|}{$\mathrm{n}$} & \multicolumn{1}{c|}{$\mathrm{n}$} & \multicolumn{1}{c|}{$\%$} & $\mathrm{n}$ & \multicolumn{1}{c|}{$\%$} & \multicolumn{1}{c|}{$\mathrm{n}$} & \multicolumn{1}{c|}{$\%$} \\
\hline Pendapatan Total Keluarga & 7 & 4.2 & 87 & 51.8 & 65 & 38.7 & 9 & 5.4 \\
\hline Pengeluaran pangan Keluarga & 2 & 1.2 & 52 & 31.0 & 33 & 19.6 & 81 & 48.2 \\
\hline Pengeluaran non pangan keluarga & 54 & 32.1 & 15 & 8.9 & 24 & 14.3 & 75 & 44.6 \\
\hline Jumlah Makanan Keluarga & 3 & 1.8 & 80 & 47.6 & 76 & 45.2 & 9 & 5.4 \\
\hline Kualitas Hubungan dalam Keluarga & 7 & 4.2 & 5 & 3.0 & 140 & 83.3 & 16 & 9.5 \\
\hline Jumlah Tabungan Keluarga & 155 & 92.3 & 3 & 1.8 & 7 & 4.2 & 3 & 1.8 \\
\hline Konflik/pertengkaran dalam Keluarga & 6 & 3.6 & 27 & 16.1 & 4 & 2.4 & 131 & 78.0 \\
\hline Kekerasan dalam rumahtangga & 0 & 0.0 & 6 & 3.6 & 2 & 1.2 & 160 & 95.2 \\
\hline Kualitas Pendidikan anak & 82 & 48.8 & 16 & 9.5 & 70 & 41.7 & 0 & 0.0 \\
\hline Kualitas Kesehatan keluarga & 10 & 6.0 & 43 & 25.6 & 114 & 67.9 & 1 & 0.6 \\
\hline Hubungan sosial dengan tetangga & 6 & 3.6 & 2 & 1.2 & 123 & 73.2 & 37 & 22.0 \\
\hline Kualitas pekerjaan & 17 & 10.1 & 75 & 44.6 & 73 & 43.5 & 3 & 1.8 \\
\hline Jumlah penguasaan aset (JUAL, & 76 & 45.2 & 29 & 17.3 & 62 & 36.9 & 1 & 0.6 \\
GADAI) & & & & & & & & \\
\hline
\end{tabular}

Pemrakarsa dalam Melakukan Strategi Coping Keluarga

Berdasarkan hasil penelitian ternyata ada kecenderungan bahwa survival strategi (strategi coping) keluarga yang dilakukan merupakan hasil diskusi antara suami dan isteri. Hal ini ditunjukkan oleh proporsi tertinggi responden (lebih dari 50\%) yang menyatakan bahwa dalam melakukan beberapa survival strategi keluarga seperti mengurangi biaya transport dengan naik sepeda/jalan/ numpang, mengurangi biaya kesehatan, bekerja lembur/tambahan untuk meningkatkan pendapatan, menjual aset, menggadaikan barang, mengambil tabungan, dan mengurangi biaya pendidikan anak (anak putus sekolah/sering bolos) diprakarsai oleh suami dan isteri. Sedangkan proporsi tertinggi (lebih dari 50\%) yang menyatakan bahwa survival strategi yang dilakukan merupakan prakarsa isteri saja terdapat pada beberapa kegiatan seperti mengurangi konsumsi pangan, hutang/ meminjam, dan mengganti minyak tanah dengan kayu bakar untuk memasak. Peran suami secara tunggal dalam memprakarsai survival strategi yang dilakukan oleh keluarga ternyata masih rendah. Hal ini terlihat dari proporsi responden yang kecil (kurang dari $6 \%$ ) menyatakan bahwa survival strategi yang dilakukan adalah diprakarsai suami.

Survival Strategi Keluarga Sebelum dan Sesudah Kenaikan Harga BBM

Survival strategi keluarga yang paling banyak $(63.7 \%)$ dilakukan oleh responden adalah hutang/meminjam uang. Kebiasaan tersebut meningkat $(79.8 \%)$ sesudah terjadi kenaikan harga BBM. Sebelum kenaikan harga BBM, mengurangi konsumsi makan adalah salah satu survival strategi keluarga yang relatif banyak $(22.0 \%)$ dilakukan responden dan sesudah kenaikan harga BBM jumlah keluarga yang melakukan kegiatan tersebut mencapai $57.7 \%$. Peningkatan jumlah keluarga yang cukup banyak terjadi pada jenis survival strategi mengurangi biaya transpot yaitu menjadi $47.6 \%$ pada saat sesudah dari $16.7 \%$ saat sebelum kenaikan harga BBM. Mengganti minyak tanah dengan kayu bakar adalah salah satu strategi yang banyak dilakukan sesudah kenaikan harga BBM, yaitu mencapai $35.7 \%$ dari sebelumnya yang hanya $12.5 \%$ (Tabel 7). 
Tabel 7. Sebaran Responden Berdasarkan Survival Strategi Keluarga Sebelum dan Sesudah Kenaikan Harga BBM

\begin{tabular}{|c|c|c|c|c|c|c|c|c|}
\hline \multirow{3}{*}{ Strategi } & \multicolumn{4}{|c|}{ Sebelum } & \multicolumn{4}{|c|}{ Sesudah } \\
\hline & \multicolumn{2}{|c|}{ Tidak } & \multicolumn{2}{|c|}{$\mathrm{Ya}$} & \multicolumn{2}{|c|}{ Tidak } & \multicolumn{2}{|c|}{$\mathrm{Ya}$} \\
\hline & $\mathbf{n}$ & $\%$ & $\mathbf{n}$ & $\%$ & $\mathbf{n}$ & $\%$ & $\mathbf{n}$ & $\%$ \\
\hline Mengurangi konsumsi pangan & 131 & 78.0 & 37 & 22.0 & 71 & 42.3 & 97 & 57.7 \\
\hline $\begin{array}{l}\text { Mengurangi biaya transport dengan } \\
\text { naik sepeda/jalan/numpang, dll }\end{array}$ & 140 & 83.3 & 28 & 16.7 & 88 & 52.4 & 80 & 47.6 \\
\hline Mengurangi biaya kesehatan & 151 & 89.9 & 17 & 10.1 & 138 & 82.1 & 30 & 17.9 \\
\hline $\begin{array}{l}\text { Bekerja lembur/tambahan untuk } \\
\text { meningkatkan pendapatan }\end{array}$ & 150 & 89.3 & 18 & 10.7 & 132 & 78.6 & 36 & 21.4 \\
\hline Menjual aset & 154 & 91.7 & 14 & 8.3 & 130 & 77.4 & 38 & 22.6 \\
\hline Menggadaikan barang & 162 & 96.4 & 6 & 3.6 & 164 & 97.6 & 4 & 2.4 \\
\hline Hutang/ meminjam & 61 & 36.3 & 107 & 63.7 & 34 & 20.2 & 134 & 79.8 \\
\hline Mengambil tabungan & 168 & 100 & 0 & 0.0 & 163 & 97.0 & 5 & 3.0 \\
\hline $\begin{array}{l}\text { Mengurangi biaya pendidikan anak } \\
\text { (anak putus sekolah/ sering bolos) }\end{array}$ & 158 & 94.0 & 10 & 6.0 & 148 & 88.1 & 20 & 11.9 \\
\hline $\begin{array}{l}\text { Mengganti minyak tanah dengan kayu } \\
\text { bakar untuk memasak }\end{array}$ & 147 & 87.5 & 21 & 12.5 & 108 & 64.3 & 60 & 35.7 \\
\hline
\end{tabular}

Jenis survival strategi lain yang dilakukan lebih seperlima keluarga pada saat sesudah kenaikan harga BBM adalah bekerja lembur/tambahan untuk meningkatkan pendapatan $(21.4 \%)$ dan menjual aset $(22.6 \%)$. Sedangkan pada saat sebelum kenaikan harga BBM jumlah responden yang melakukan hal tersebut berkisar antara $8.3-10.7 \%$. Survival strategi yang relatif sedikit dilakukan oleh keluarga, walaupun jumlahnya meningkat setelah kenaikan harga BBM adalah mengurangi biaya kesehatan, mengambil tabungan, dan mengurangi biaya pendidikan anak (anak putus sekolah/sering bolos). Pola yang berbeda terjadi dalam hal menggadaikan barang. Keluarga yang menggadaikan barang sesudah kenaikan harga BBM menurun menjadi $2.4 \%$ dari sebelumnya $3.6 \%$. Hal ini diduga karena semakin menurunnya penguasaan aset keluarga setelah kenaikan harga BBM. Secara umum jenis survival strategi yang dilakukan keluarga sebelum dan sesudah kenaikan harga BBM adalah sama tetapi terdapat peningkatan jumlah keluarga yang melakukan survival strategi sesudah kenaikan harga BBM.
Manfaat SLT-BBM yang Dirasakan Keluarga dan Harapannya

Sebagian besar responden (48.8$86.3 \%$ ) menyatakan bahwa uang SLTBBM yang diterima memberi manfaat yang cukup dalam hal memberi dana segar untuk keluarga, membeli kebutuhan sembako, membayar hutang, memberikan ketenangan batin sesaat, memberikan motivasi hidup sesaat, menurunkan konflik keluarga, memberikan kebahagiaan sesaat, dan merasa beban berat berkurang bagi isteri. Sedangkan proporsi responden tertinggi $(64.3 \%)$ yang menyatakan bahwa uang SLT-BBM memberi manfaat sedikit adalah dalam hal membayar uang sekolah anak (Tabel 8).

Hal yang menarik dari hasil penelitian ini adalah bahwa lebih dari seperlima responden menyatakan bahwa uang SLT-BBM memberi manfaat yang tinggi terutama dalam hal memberikan ketenangan batin sesaat $(28.0 \%)$, memberi dana segar untuk keluarga (24.4\%) dan memberikan kebahagiaan sesaat (21.4\%). 
Tabel 8. Sebaran Responden Berdasarkan Manfaat SLT-BBM yang Dirasakan Keluarga dan Harapannya

\begin{tabular}{|l|r|r|r|r|r|r|}
\hline \multirow{2}{*}{\multicolumn{1}{c|}{ Manfaat }} & \multicolumn{4}{c|}{ Tingkat manfaat } \\
\cline { 2 - 7 } & \multicolumn{2}{|c|}{ Tidak ada/ sedikit } & \multicolumn{2}{c|}{ Cukup } & \multicolumn{2}{c|}{ Tinggi } \\
\cline { 2 - 7 } & $\mathbf{n}$ & \multicolumn{1}{c|}{$\%$} & $\mathbf{n}$ & \multicolumn{1}{c|}{$\%$} & \multicolumn{1}{c|}{$\mathbf{n}$} & \multicolumn{1}{c|}{$\%$} \\
\hline Memberi dana segar untuk keluarga & 45 & 26.8 & 82 & 48.8 & 41 & 24.4 \\
\hline Untuk membeli kebutuhan sembako & 32 & 19.0 & 103 & 61.3 & 33 & 19.6 \\
\hline Untuk membayar sekolah anak & 108 & 64.3 & 52 & 31.0 & 8 & 4.8 \\
\hline Untuk membayar hutang & 67 & 39.9 & 82 & 48.8 & 19 & 11.3 \\
\hline Memberikan ketenangan batin sesaat & 5 & 3.0 & 116 & 69.0 & 47 & 28.0 \\
\hline Memberikan motivasi hidup sesaat & 4 & 2.4 & 145 & 86.3 & 19 & 11.3 \\
\hline Menurunkan konflik keluarga & 52 & 31.0 & 107 & 63.7 & 9 & 5.4 \\
\hline Memberikan kebahagiaan sesaat & 3 & 1.8 & 129 & 76.8 & 36 & 21.4 \\
\hline Istri merasa beban berat berkurang & 23 & 13.7 & 122 & 72.6 & 23 & 13.7 \\
\hline
\end{tabular}

Jika dilihat berdasarkan kategori manfaat maka sebagain besar keluarga $(70.8 \%)$ menyatakan bahwa uang SLT cukup bermanfaat. Sedangkan sebanyak $22.6 \%$ keluarga memiliki manfaat yang rendah dan hanya $6.5 \%$ yang termasuk kategori manfaat tinggi (Tabel 9).

Tabel 9. Sebaran Keluarga berdasarkan Kategori Manfaat Uang SLT-BBM

\begin{tabular}{|l|c|c|}
\hline \multicolumn{1}{|c|}{ Kategori } & $\mathbf{n}$ & $\mathbf{\%}$ \\
\hline Sedikit (9-15) & 38 & 22.6 \\
\hline Cukup (16-22) & 119 & 70.8 \\
\hline Tinggi (23-27) & 11 & 6.5 \\
\hline Total & 168 & 100 \\
\hline
\end{tabular}

Tingkat Kepuasan terhadap Keadaan Kehidupan dan Gaya Manajemen Sumberdaya

Manajemen Sumberdaya Saat Ini. Secara umum responden menyatakan cukup puas terhadap gaya manajemen sumberdaya saat ini. Hal ini ditunjukkan oleh lebih dari $80 \%$ responden menyatakan cukup puas terhadap keadaan spiritual/mental, gaya manajemen waktu, gaya manajemen keuangan, gaya manajemen stress, gaya manajemen pekerjaan, dan optimisme menyongsong masa depan. Selain itu juga terdapat sekitar $50-75 \%$ responden menyatakan cukup puas juga terhadap keadaan makanan, keadaan tempat tinggal, keadaan kesehatan fisik, keadaan pendidikan anak, hubungan/komunikasi dengan orang tua, hubungan/komunikasi dengan saudara, hubungan/ komunikasi dengan teman, hubungan/ komunikasi dengan tetangga, manfaat SLT-BBM bagi keluarga, antrian untuk mendapatkan uang SLT-BBM, dan proses pendataan sebelum mendapatkan SLT-BBM termasuk verifikasi kriteria kemiskinan. Bahkan untuk masalah komunikasi dengan orang tua, saudara, teman maupun tetangga, lebih dari sepertiga responden menyatakan puas sekali.

Sebaliknya untuk keadaan pendidikan anak, keadaan tempat tinggal, besaran uang SLT-BBM Rp $100.000 /$ bulan dan antrian untuk mendapatkan uang SLT, lebih sepertiga responden menyatakan tidak puas. Kondisi yang tidak puas juga banyak dinyatakan responden (lebih dari $50 \%$ ) dalam hal keadaan keuangan dan keadaan materi/aset. Pada saat ini hanya sedikit sekali (kurang dari 2\%) responden yang menyatakan puas sekali terhadap keadaan keuangan dan makanan.

Jika dikelompokkan menjadi tiga kategori maka sebagian besar responden (91.7\%) termasuk kategori cukup puas terhadap keadaan kehidupan dan gaya manajemen sumberdaya saat ini. Walaupun demikian masih ditemukan sebanyak $6.5 \%$ responden yang termasuk kategori kurang puas dan hanya sebagian kecil saja yang termasuk ategori puas sekali terhadap keadaan 
kehidupan dan gaya manajemen sumberdaya saat ini (Tabel 10).

Harapan Terhadap Kelangsungan $S L T$-BBM. Sebagian besar responden menyatakan tidak setuju terhadap beberapa pernyataan seperti SLT$\mathrm{BBm}$ dihentikan dalam waktu dekat karena tidak mendidik (84.5\%), SLTBBM membuat orang jadi malas karena tidak mendidik (89.9\%), dan SLT-BBM diberikan pada pemuda yang masih gagah (96.4\%). Sebaliknya sebagian besar responden menyatakan sangat setuju terhadap beberapa pernyataan seperti SLTBBM diberikan seterusnya, apapun kata orang $(77.1 \%)$, jumlah uang SLT inginnya dinaikkan (81.5\%), SLT-BBM diberikan pada janda-janda tua yang memerlukan $(77.4 \%)$, dan anak yatim (69.6\%). Sedangkan jika SLT-BBM diganti dengan bantuan modal tanpa agunan namun harus digunakan untuk modal kerja, ditanggapi dengan tidak setuju oleh $43.5 \%$ responden, setuju $41.1 \%$, dan sisanya

$(15.5 \%)$ menyatakan sangat setuju.

Tabel 10. Sebaran Responden berdasarkan Kepuasan terhadap Keadaan Kehidupan dan Gaya Manajemen Sumberdaya

\begin{tabular}{|l|c|c|}
\hline \multicolumn{1}{|c|}{ Kategori } & $\mathbf{n}$ & $\mathbf{\%}$ \\
\hline Kurang puas (20-33) & 11 & 6.5 \\
\hline Cukup puas (34-47) & 154 & 91.7 \\
\hline Puas sekali (48-60) & 3 & 1.8 \\
\hline Total & 168 & 100 \\
\hline
\end{tabular}

Tabel 11. Sebaran responden Berdasarkan Harapan terhadap Kelangsungan SLT-BBM

\begin{tabular}{|c|c|c|c|c|c|c|}
\hline \multirow[t]{2}{*}{ Pernyataan } & \multicolumn{2}{|c|}{$\begin{array}{l}\text { Tidak } \\
\text { Setuju }\end{array}$} & \multicolumn{2}{|c|}{ Setuju } & \multicolumn{2}{|c|}{$\begin{array}{l}\text { Sangat } \\
\text { Setuju }\end{array}$} \\
\hline & $\mathbf{n}$ & $\%$ & $\mathbf{n}$ & $\%$ & $\mathbf{n}$ & $\%$ \\
\hline SLT-BBM diberikan seterusnya, apapun kata orang & 12 & 7.1 & 26 & 15.5 & 130 & 77.4 \\
\hline $\begin{array}{l}\text { SLT-BBM dihentikan dalam waktu dekat karena tidak } \\
\text { mendidik }\end{array}$ & 142 & 84.5 & 26 & 15.5 & 0 & 0.0 \\
\hline $\begin{array}{l}\text { SLT-BBM diganti dengan bantuan modal tanpa agunan } \\
\text { namun harus digunakan untuk modal kerja }\end{array}$ & 73 & 43.5 & 69 & 41.1 & 26 & 15.5 \\
\hline $\begin{array}{l}\text { Kata orang, SLT-BBM membuat orang jadi malas karena } \\
\text { tidak mendidik }\end{array}$ & 151 & 89.9 & 13 & 7.7 & 4 & 2.4 \\
\hline Jumlah uang SLT-BBM pinginnya dinaikkan & 2 & 1.2 & 29 & 17.3 & 137 & 81.5 \\
\hline SLT-BBM diberikan pada pemuda yang masih gagah & 162 & 96.4 & 4 & 2.4 & 2 & 1.2 \\
\hline SLT-BBM diberikan pada janda-janda tua yang memerlukan & 2 & 1.2 & 36 & 21.4 & 130 & 77.4 \\
\hline SLT-BBM diberikan pada anak-anak yatim & 2 & 1.2 & 49 & 29.2 & 117 & 69.6 \\
\hline
\end{tabular}

\section{SIMPULAN DAN SARAN}

Simpulan

Berdasarkan hasil penelitian ditemukan bahwa sekitar setengah dari jumlah rumah tangga miskin dinyatakan salah sasaran atau tidak layak mendapatkan dana SLT-BBM. Rumah tangga contoh yang memenuhi 9 kriteria atau lebih dari aturan yang ditetapkan oleh BPS (2005) hanya sebesar $45 \%$ saja. Namun demikian, kalau ditinjau dari sudut besarnya pendapatan yang diperoleh, rata-rata pendapatan keluarga contoh per bulan sebagian besar (75\%) di bawah Rp 750,000.00 untuk KK laki-laki dan di bawah Rp 500,000.00 untuk KK perempuan. Apalagi kalau dilihat dari rata-rata pendapatan per kapita per bulan, maka sebanyak $60 \%$ keluarga contoh berada di bawah Rp 100,000.00 atau di bawah garis kemiskinan, yaitu untuk Kota Bogor Rp 133,803.00 per kapita per bulan dan Kabupaten Bogor Rp 105,588.00 per kapita per bulan (Garis Kemiskinan tahun 2003).

Masalah terbesar yang diakui oleh keluarga contoh adalah berujung dari masalah ekonomi. Oleh karena itu strategi pemecahan yang dilakukan terdiri atas dua cara. Strategi pertama dilakukan dengan cara berhemat atau mengurangi pengaluaran-pengeluaran 
untuk biaya pangan, transport, dan kesehatan, atau dengan cara mensubstitusi penggunaan bahan bakar untuk memasak dari minyak tanah ke kayu bakar yang lebih murah. Strategi kedua adalah dengan cara menambah jumlah ketersediaan sumberdaya keluarga dengan cara bekerja lembur, menjual asset, menggadaikan barang, atau berhutang.

Apabila dilihat dari pemrakarsa dalam melakukan coping strategy atau kiat-kiat dalam mengatasi kesulitan hidup, maka terbukti bahwa perempuan berperan sangat aktif dalam mencari ide dan melaksanakan ide tersebut agar keluarganya dapat memenuhi kebutuhan sehari-hari. Apabila ditelaah lebih lanjut, maka keterlibatan istri saja yang mempunyai prakarsa dalam survival strategy adalah kurang dari setengah jumlah contoh, sedangkan keterlibatan bersama antara istri dan suami adalah sekitar setengahnya. Adapun keterlibatan suami saja dalam berprakarsa agar keluarganya tetap bertahan hidup dalam memenuhi kebutuhannya hanya kurang dari $5 \%$ saja. Dengan demikian membuktikan bahwa peran perempuan dalam bertanggung jawab dalam kelangsungan hidup sehari-hari adalah sangat dominan dan penting.

Program SLT-BBM dirasakan banyak manfaatnya bagi keluarga miskin. Diketahui bahwa sekitar setengah dari jumlah dana SLT diprioritaskan untuk kebutuhan pangan pokok (sesuai dengan tahapan kebutuhan Maslow). Selanjutnya, kurang dari sepertiganya dialokasikan untuk kebutuhan non-pangan, seperti perumahan, pendidikan, kesehatan, pakaian, dan rokok. Bahkan sebagian lagi dialokasikan untuk membayar hutang atau untuk modal usaha. Sayangnya, dana SLT-BBM yang diperuntukkan untuk modal usaha adalah sangat kecil, yaitu kurang dari lima\%. Sepertinya keluarga contoh memang sangat terbatas sumberdaya keuangannya, sehingga dana SLTBBM ini langsung dialokasikan untuk kebutuhan pokok saja. Hal ini juga terbukti apabila dilihat dari jangka waktu lamanya dana SLT-BBM habis, yaitu kurang dari seminggu.

\section{Saran}

Meskipun para responden menginginkan adanya Program SLTBBM ini diberikan selamanya (karena menurut keluarga miskin sangat membantu dalam mengatasi kebutuhan hidup sehari-hari), namun mengingat benefit yang dirasakan hanya sesaat, sedangkan biaya sosial dan biaya ekonomi hutang luar negeri yang ditanggung oleh seluruh bangsa Indonesia adalah dalam jangka waktu panjang, maka penelitian ini merekomendasikan sebagai berikut:

1. Bantuan SLT-BBM diberikan dalam bentuk lain, misalnya dikaitkan dengan human investment, seperti modal kerja berkelompok atau disalurkan ke keluarga miskin melalui institusi pendidikan dasar;

2. untuk kelompok masyarakat tertentu, misalnya golongan handicapp disalurkan melalui balai latihan kerja khusus; untuk kelompok lanjut usia dan masyarakat tertinggal disalurkan melalui Departemen Sosial;

3. untuk kelompok anak yatim disalurkan melalui Departemen Sosial.

Penelitian ini merekomendasikan agar pemberian subsidi untuk rakyat harus dipaketkan dengan strategi pemberdayaan masyarakat, baik berkaitan dengan human investment atau aktivitas ekonomi, agar uang yang disalurkan ke rakyat dapat mempunyai multiplier effect di kemudian hari.

\section{DAFTAR PUSTAKA}

[BPS] Biro Pusat Statistik. 1998. Profil Wanita Kepala Rumah Tangga. Jakarta: BPS. 
Djalil, S.A. 2005. Latar Belakang dan Kebijaksanaan Mengenai BBM. http://www.depkominfo.co.id [09 April 2006].
Suhartiningsih, W. 2005. Dana Kompensasi BBM dan Jaminan Sosial. http://www.uplink.or.id [09 April 2006].

1 Staf Pengajar Departemen IImu Keluarga dan Konsumen, FEMA IPB

2 Staf Pengajar Departemen IImu Keluarga dan Konsumen, FEMA IPB

3 Staf Pengajar Departemen Manajemen, FEM IPB 